Volume 7 |No. 2 | July - December 2020

\title{
Determinants of residents' support for Tourism development- A Pilot Study
}

\author{
Zaibunnisa Khan ${ }^{1}$, Mubashir Ali Khan ${ }^{1}$
}

\begin{abstract}
:
This pilot study aims to test the reliability and validity of the survey instrument designed to find out the determinants of residents' support for tourism. Since the study uses an adapted questionnaire the need to assess the reliability and validity appears to be desirable. The questionnaire was distributed to altogether 70 residents of Hunza Valley. Initially, the content and face validity was authenticated by field experts, and later on, the internal construct validity was calculated through various measures. Hence, inter-item correlation shows that all the variables are correlated to each other at a significant level. Secondly, construct validity results show that all the constructs used by the study are reliable and met the level of acceptability. Therefore, the results validate that the modified instrument is valid and reliable in the context of the social lab selected i.e. residents of Hunza Valley, and a full large scale study can be carried out using this instrument.
\end{abstract}

Keywords: tourism impact, tourism impact dimensions, residents' support for tourism, reliability, and validity.

\section{JEL Classification: M10}

\section{Introduction}

Over the decades, tourism has been developing and diversifying constantly which has led this industry to grow into a profitable industry with the fastest growth on the globe. The growing number of tourist destinations around the world and people's increasing inclination towards tourism has played a major role in this growth. This in turn helped this industry to become a leading socio-economic factor. The business dimensions today of this industry are far more than the traditional ones which make tourism the most significant part of global business and a leading revenue generation source for developed and developing countries.

Pirnar \& Günlü, (2012) found that constant growth in the tourism industry has risen the incomes and competition which resulted in increased demand for improved

${ }^{1}$ Management Sciences Department Bahria University Karachi Campus Corresponding Author: makhan.bukc@bahria.edu.pk 
management and marketing strategies and made the survival of inefficient firms quite difficult at the same time. Subsequently, the tourism industry has been supported by these management and marketing strategies by many theorists. It has been found that once a particular place has become a destination for tourism it can affect the lives of residents both positively and negatively.

The phrase "tourism impacts" has acquired prominence in the literature of tourism. This "impact" can be measured by the assessment of residents of the host community (Almeida et al, 2016). The key reason for the growing interest in this area is the knowledge and awareness of tourism development and its impact on the local community, both positively and negatively (Ko \& Stewart, 2002). Recent studies have found that the money generated from tourism does not only impact the country at large but also benefits the individual communities and their residents through increased employment opportunities, higher incomes, and advanced public infrastructures (Sinclair \& Gursoy, 2016). Despite the fact, when residents experience the benefits of tourism for the first time, they are also getting started to understand that these advantages are complemented by disadvantages (Ko \& Stewart, 2002). For instance, tourism leads to monetary growth however it also brings ecological deterioration and negative socio-cultural impacts on the residents (Choi \& Sirakaya, 2005). Consequently, by reviewing the literature it appears that the tourism impacts can be studied from various aspects, such as environmental, economic, social, and cultural (K. Kim et al, 2013).

Furthermore, these tourism impacts, both positive and negative, on the life of residents of the host community can be best explained by social exchange theory (SET). As various studies conducted previously underpin the SET, particularly relating to monetary benefits that increase the tourism development support (Juan et al, 2014; Dogan et al, 2018; Nunkoo \& So, 2016; Perdue et al, 1999; Pizam, 1978; Woo et al 2015); as well as the Quality of Life (QOL) issues of the residents demonstrating the more the personal advantage an individual gets the more positive their perception is formed towards the tourism(Woo et al, 2015; Woo et al, 2016).

It is said that the development of tourism does not take place exclusively; instead, it takes place within particular surroundings with its unique features. With these particular surroundings, the support of residents is said to be a major reason in tourism development (Butler, 1980; Dyer et al., 2007). Therefore, most of the researchers found this as a necessity to include the residents in the planning phases of tourism development (Liu et al, 1987). Additionally, it is found that Observing residents' perception is essential in measuring their emotional state, and such observations should be integrated into tourism development schemes. It will help organizers to concentrate on what is essential for the residents to considerate (Dyer et al., 2007). Particularly, knowing residents' perceptions may result in strategies that can reduce negative impacts on tourism development and maximize the benefit (Stylidis et al, 2014). Further, it has been noted that if residents are involved in the process of decision making of tourism development and planning, they are likely to have positive perceptions of tourism (Robson \& Robson, 1996). Irrespective of the significance of the residents' perceptions towards tourism the measures that could be taken by local government and 
administration are not sufficient and do not favor host community residents in taking part in the decision-making process. Political enterprises concerning the sustainability of tourism and growth can be more effective if residents are permitted to make their own wishes, objectives, and needs, and also by giving chances to get advantage from tourism both socially and economically (Almeida et al, 2016).

To measure the residents' support for tourism and its determinants this pilot study aims to test the reliability and validity of the survey instrument. A thoroughly established survey instrument if precisely measures any well-defined construct is considered to be a valid instrument for that construct. An instrument is said to be valid when it evaluates what is claimed to assess. Validity can be classified into; content validity, Face validity, criterion validity, and construct validity. Content validity pertains to the degree to which the instrument fully assesses or measures the construct of interest. Whereas face validity, which is also known as logical validity, is a simple form of validity where an expert applies a superficial and subjective assessment of whether or not the study measures what it is supposed to measure. Criterion validity is verified in the actual study to improve its requirement. It requires an in-depth knowledge of philosophy linking to the notion and measure of the relationship between measure and factors. Finally, the construct validity is used to check an instrument to accurately measure a theoretical construct that it is designed to measure. Furthermore, on the other hand, the reliability measures in which test scores are free from measurement error. Reliability concerns the measurement of a phenomenon that delivers consistent and stable results. It is a measure of internal consistency or stability of an instrument measuring certain notions.

The present study provides the social lab contribution in the existing literature, as in the Pakistani context limited literature is available on tourism studies. However, tourism studies concerning residents' perceptions of tourism impacts, their QOL, and their support for tourism development have not been reported yet in any dimension. Therefore, the findings of this study will considerably contribute to the body of knowledge of this specific area.

\section{Literature Review}

It has become clear that a plethora of research studies investigated the perception of residents towards tourism impacts as well as those factors which influence these perceptions potentially, pointing to recognize the methods that would sustain or increase residents' Support for Tourism (SFT) development. Although several predictors have been examined in previous research studies, most of these studies did not examine the simultaneous impact of these factors together. Focusing to overcome this limitation, in the last decade, researchers have established and tested structural models for residents' SFT development, which investigates the simultaneous effect of various key variables of residents' perception of tourism impacts, which in turn affect residents' SFT and its development. Even though the factors considered in these models sometimes differ, but a common finding is that the residents' perception of tourism impacts seems to affect their SFT development. A plethora of literature examines the affiliations between residents' perceived impacts of tourism and their SFT development 
(Wan \& Stewart, 2002; Dogan et al, 2002; Jurowski \& Gursoy, 2004; Nunkoo \& Ramkissoon, 2010). Since tourism depends severely upon the goodwill of the residents, their support is important for its development, as well as for its success and sustainability in the long term, the understanding of residents' perceptions and encouragement of such support is of great significance for local government, policymakers and business (Lee, 2013).

According to Nunkoo \& Ramkissoon, (2011) to follow the successful development process, a host destination needs to be supported by its residents. A potential justification for why resident support tourism is the SET. From the residents' point of view, this theory grasps that people tend to trade their SFT in exchange for the advantages they stand to get from tourism, in other words; residents SFT will depend on the benefits that they will get in return from tourism existence. Therefore it is by assessing the social, economic, environmental, and cultural concerns of the residents' on which they decide whether to support tourism or not (Lee, 2013). It means, if there are some benefits for them and comparatively decreases in social costs, then the residents are more likely to support tourism development (Ap, 1992).

Almost from the three decades, building upon the SET, several pieces of research have been conducted by presenting models to highlight the association of residents' perception of impacts of tourism and their support for the future tourism development. Probably, Perdue et al, (1990) presented the first conceptual framework on residents' SFT development. This framework was based on the individuals' characteristics and advantages from tourism which influences residents' perceptions of tourism impacts (both positive and negative), which in result affects residents' SFT. Furthermore, the study found that residents' SFT is positively related to the positive impacts and negatively related to the negative tourism impacts. This study inspired several researchers, thereafter several models have been proposed using the common structure. Jurowski et al, (1997) presented a path model in the background of the theoretical paradigm which is grounded on the principles of SET. The study revealed that the residents' perceptions of tourism impacts directly influence the "use of tourism resources", "economic gain", "eco-centric attitude" and "community attachment" and indirectly influence the level of SFT. Snaith \& Haley, (1999) perceived that those residents who were monetarily dependent on tourism showed a positive and greater level of SFT. later, a simplified model was proposed by Yoon et al, (2001) where perceived tourism impacts (economic, social, environmental, and cultural) affect the perception of overall impacts, which in result influence the residents' SFT. The study concluded that tourism impacts positively influence residents' SFT. Whereas, Iroegbu $\&$ Chen, (2001) found in their study that those urban residents (specifically male) having higher education and greater income are more inclined to SFT development. Moreover, many studies' conclusions confirmed that there is a direct positive association between perceived benefits from tourism and residents SFT ( Andereck \& Vogt, 2000; Dogan Gursoy et al, 2002). Because, If the perception of residents' are positive towards tourism impacts, then the residents will possibly support tourism development and express more hospitality to tourists. Generally, the tourists are more satisfied and appealed by those destinations where residents are more welcoming, 
honest, friendly, and hospitable (Fallon \& Schofield, 2006; Lin et al, 2017). Other scholars like Choi \& Murray, (2010) investigated residents perceptions regarding SFT and the acceptance of sustainable tourism by using SET, the outcomes of the study showed that the three main constructs of sustainable tourism (tourism long term planning, community participation, and its attachment) are analytically linked to SFT, positive tourism impacts, and negative tourism impacts. Stylidis et al, (2014) proposed a model that confirmed that residents' place image has an emotional impact on their perceptions of impacts of tourism, which in turn influence their SFT. Further, the study revealed that the more positive tourism impacts dimensions lead to residents' greater SFT. As well as residents are more prepared to support tourism development policies (Brida et al, 2014).

Most of the early studies have considered the QOL as the main outcome variable in preceding tourism impacts literature (Kim, 2002; Kim et al, 2013). Improvement of the residents' QOL has become the key purpose of tourism growth by addressing the tourism impacts dimensions such as social, economic, cultural, and environmental impacts (Peters \& Schuckert, 2014). Over the past few years, the association between the QOL of the residents and tourism development has been achieving an excessive amount of attention. It is also acknowledged that the success of tourism growth in the long stand needs to consider the host residents' perceptions and taken into account in the growth process of tourism (Nunkoo \& Ramkissoon, 2011). However, residents can also influence their attitude about SFT growth. Many studies have proposed the potential impact of QOL on further SFT development, but there was no empirically tested results were available (Andereck et al, 2007; Ap, 1992; Croes, 2012).

Later, a new and unique model was proposed by Woo et al, (2015) which provides the theoretic and empirical verification of the relationships among the variables, the study evaluates the residents' SFT through its determinants, the perceived value of tourism development, life domain satisfaction, and their QOL. Further, the study revealed that the residents' QOL is an effective predictor of their SFT. The study also provides empirical evidence to support previous researches by investigating tourism impacts development on the QOL. Moreover, the study discovered a new relationship that explicitly states that the QOL has a positive impact on residents' perception of tourism support. Therefore, if the impacts of tourism growth affect the residents' QOL negatively, then the residents could not SFT growth in their community. Thus to create the community more sustainable and economical, tourism developers and marketers should attempt to escalate the residents' QOL. Therefore, another purpose of this study is to investigate the impact of residents' QOL on their SFT growth.

\section{Data And Methodology}

This study uses content validity, face validity, criterion validity, and construct validity to assess the validy of the survey instrument adapted for this study. At the same time, the reliability of the instrument is also checked with Cronbach's alpha. The survey instrument was pretested on a sample of 70 residents of Hunza valley who were both employed and self-employed. The pretest was essential to conduct to make sure the 
accuracy of the instrument was used. The questionnaire adopted in this study was established after a comprehensive literature review. The questionnaire is divided into three sections with a total of 61 items concerning the social lab of the study which is the resident (individual) of Hunza Valley. The survey questionnaire comprises of the residents' demographic characteristics and the dimension of tourism impacts (economic, social, cultural, and environmental), dimensions of residents' quality of life (material wellbeing, community wellbeing, emotional wellbeing, health \& safety wellbeing, and quality of life in general), and residents' support for tourism. This study follows a cross-sectional research design to conduct a questionnaire survey. Following non-probability sampling, purposive sampling technique was used to collect the data. Further, the study used two different kinds of five-point Likert scale. The tourism impact dimensions \& residents' SFT was answered through five points Likert scale ranges from 1 (strongly disagree) to 5 (strongly agree), whereas residents' QOL was answered through five points Likert scale ranges from 1 (very unsatisfied) to 5 (very satisfied) to quantify the items. For pretest, content and face validity were also conducted before the data collection. Statistical analysis was conducted through SPSS 23 version. The internal consistency of the item scales was assessed by using Cronbach's alpha along with intra-class correlation coefficients. Further, criterionrelated validity through correlation coefficient and internal construct validity were also analyzed by inter-item correlations and co-variances.

\section{Data Analysis \& Results}

\subsection{Face and content validity}

Validity refers to the degree to which a measurement determines what it is aimed to measure (Rosenthal \& Rosnow, 1984). One of the types of validity is face validity. It is a subjective and superficial assessment of whether the measurement used in a study appears to be a valid measure of a given variable or construct. It is also called surface validity or appearance validity. Whereas, content validity refers to how adequately measurement tool taps into the various aspects of the construct in question. For assessing content and face validity two subject experts and one field expert were asked to provide comments on the content and understandability of the questionnaire. The experts were requested to edit and improve the items of the questionnaire if necessary to enhance clarity, understandability, readability, and content adequacy. Additionally, they were also asked to revise the items that were incomprehensive and needed to be improved. After a detailed review, the questionnaire was validated by the experts, and few changes were suggested, which was incorporated accordingly.

\subsection{Construct validity and reliability}

To assess the construct validity and reliability the tests of the intra-class correlation coefficient, inter-item correlations and co-variances, criterion-related validity through correlation coefficient, and internal consistency through Cronbach's alpha were

Sukkur IBA Journal of Management and Business - SIJMB | Vol 7 No. 2 July - December 2020 @ Sukkur IBA University 
performed respectively and are presented below.

\subsubsection{Reliability statistics}

Cronbach's, (1951), reliability test was performed to check the internal consistency of the variables, for that the Cronbach's alpha value was recommended to be 0.7 or above, for an acceptable level of internal consistency. As higher values indicate the strong internal consistency and reliability among the items (Burns \& Burns, 2008; Field, 2013). In support, Sekaran \& Bougie, (2016), stated that the value of Cronbach's Alpha is accepted at 0.70 or above in most of the social science and business research.

The table below shows the reliability statistics of the items used in this study.

Table 1: Reliability Statistics scores

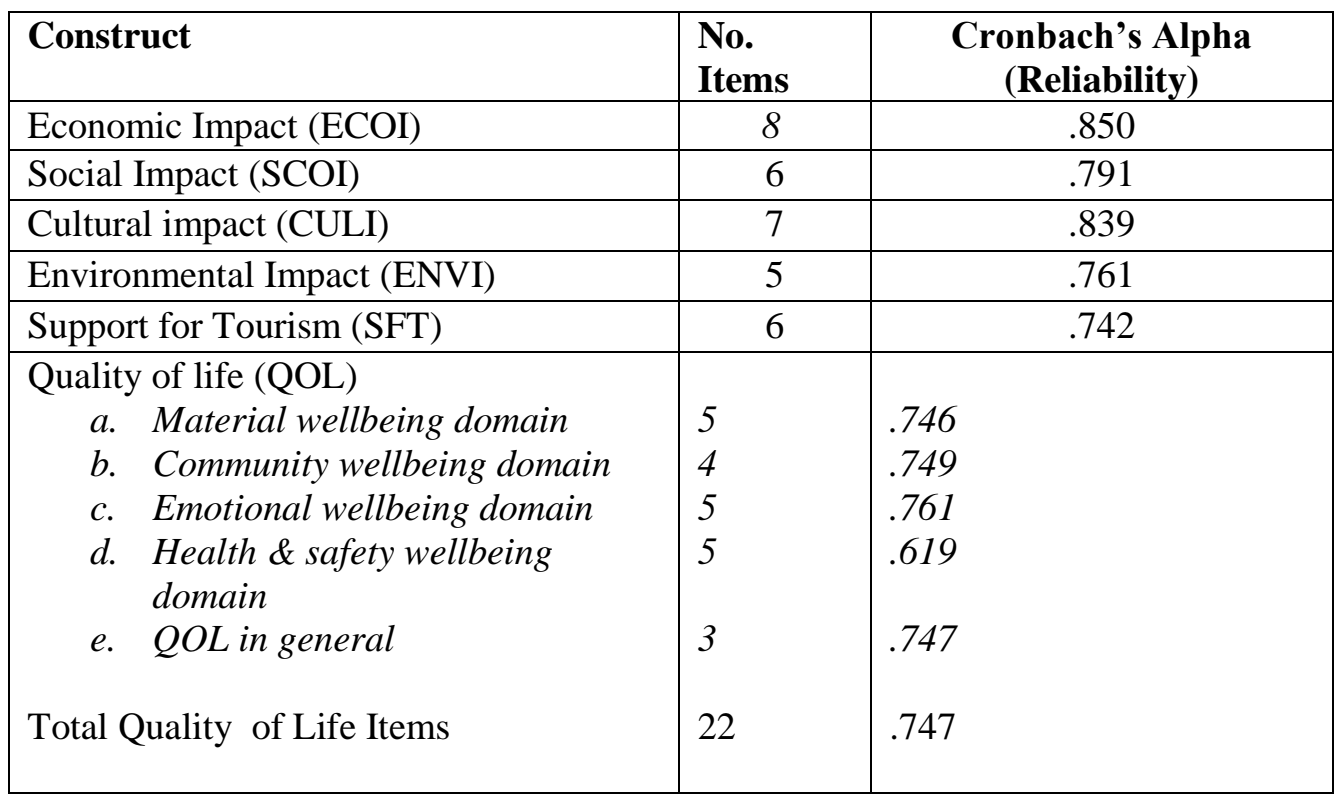

The above table shows that the reliability statistics of the items which confirm the acceptable level of internal consistency, which is above 0.7, showing the excellent internal consistency of the items. However, the reliability of health \& safety wellbeing (.619) turns out to be slightly lower than the threshold. The reason may be the smaller number of respondents which can be further improved by increasing the number of responses.

\subsubsection{Intra-class correlation coefficient}

Another way to determine the reliability of the measurements is the intra-class 
correlation (ICC). ICC represents the set of coefficients which represent the relationship between variables of the same class. The ideal value of ICC is considered to be more than 0.9 i.e., excellent reliability, the values lying between the ranges of 0.75 to 0.9 represent good reliability, values ranging from 0.5 to 0.75 represent moderate reliability, and the values less than 0.5 represent poor reliability.

The tables below show the intra-class reliability of all the variables used in this study. The values for intra-class correlation of Economic impact (.850), Social impact (.791), Cultural impact (.839), Environmental impact (.739), material wellbeing (.746), Community wellbeing (.749), emotional wellbeing (.761), overall QOL (.747) and support for tourism (.742), and health \& safety wellbeing (.619), (.770), indicate that all these values fall within the ranges of moderate to excellent reliability of the ratings of this study.

Table 2: Intra-class Correlation Coefficient

\begin{tabular}{|c|c|c|c|}
\hline Variable & Measure & Intra-class & Sig \\
\hline \multirow[t]{2}{*}{ Economic Impact } & $\begin{array}{l}\text { Single } \\
\text { Measures }\end{array}$ & $.415^{\mathrm{a}}$ & .000 \\
\hline & $\begin{array}{l}\text { Average } \\
\text { Measures }\end{array}$ & $.850^{\mathrm{c}}$ & .000 \\
\hline \multirow[t]{2}{*}{ Social Impact } & $\begin{array}{l}\text { Single } \\
\text { Measures }\end{array}$ & $.387^{\mathrm{a}}$ & .000 \\
\hline & $\begin{array}{l}\text { Average } \\
\text { Measures }\end{array}$ & $.791^{\mathrm{c}}$ & .000 \\
\hline \multirow[t]{2}{*}{ Cultural Impact } & $\begin{array}{l}\text { Single } \\
\text { Measures }\end{array}$ & $.427^{\mathrm{a}}$ & .000 \\
\hline & $\begin{array}{l}\text { Average } \\
\text { Measures }\end{array}$ & $.839^{\mathrm{c}}$ & .000 \\
\hline \multirow[t]{2}{*}{ Environmental Impact } & $\begin{array}{l}\text { Single } \\
\text { Measures }\end{array}$ & $.321^{\mathrm{a}}$ & .000 \\
\hline & $\begin{array}{l}\text { Average } \\
\text { Measures }\end{array}$ & $.739^{c}$ & .000 \\
\hline \multirow[t]{2}{*}{ Material wellbeing domain } & $\begin{array}{l}\text { Single } \\
\text { Measures }\end{array}$ & $.370^{\mathrm{a}}$ & .000 \\
\hline & $\begin{array}{l}\text { Average } \\
\text { Measures }\end{array}$ & $.746^{\mathrm{c}}$ & .000 \\
\hline Community wellbeing domain & $\begin{array}{l}\text { Single } \\
\text { Measures }\end{array}$ & $\begin{array}{l}.428^{\mathrm{a}} \\
.749^{\mathrm{c}} \\
\end{array}$ & $\begin{array}{l}.000 \\
.000 \\
\end{array}$ \\
\hline
\end{tabular}

Sukkur IBA Journal of Management and Business - SIJMB | Vol 7 No. 2 July - December 2020 ๑ Sukkur IBA University 


\begin{tabular}{|c|c|c|c|}
\hline & $\begin{array}{l}\text { Average } \\
\text { Measures }\end{array}$ & & \\
\hline Emotional wellbeing domain & $\begin{array}{l}\text { Single } \\
\text { Measures } \\
\text { Average } \\
\text { Measures }\end{array}$ & $\begin{array}{l}.389^{\mathrm{a}} \\
.761^{\mathrm{c}}\end{array}$ & $\begin{array}{l}.000 \\
.000\end{array}$ \\
\hline Health \& Safety wellbeing domain & $\begin{array}{l}\text { Single } \\
\text { Measures } \\
\text { Average } \\
\text { Measures }\end{array}$ & $\begin{array}{l}.245^{\mathrm{a}} \\
.619^{\mathrm{c}}\end{array}$ & $\begin{array}{l}.000 \\
.000\end{array}$ \\
\hline The overall quality of life & $\begin{array}{l}\text { Single } \\
\text { Measures } \\
\text { Average } \\
\text { Measures }\end{array}$ & $\begin{array}{l}.496^{\mathrm{a}} \\
.747^{\mathrm{c}}\end{array}$ & $\begin{array}{l}.000 \\
.000\end{array}$ \\
\hline Support for tourism & $\begin{array}{l}\text { Single } \\
\text { Measures } \\
\text { Average } \\
\text { Measures }\end{array}$ & $\begin{array}{l}.324^{\mathrm{a}} \\
.742^{\mathrm{c}}\end{array}$ & $\begin{array}{l}.000 \\
.000\end{array}$ \\
\hline
\end{tabular}

\subsubsection{Construct Validity through Inter-item Correlations and Co-variances}

The validity of a construct is assessed to test its accuracy i.e. what is to be estimated through this particular measurement. In this pilot study, the divergent, as well as convergent validity of the constructs, were measured. The convergent validity is frequently measured through the Average variance extracted (AVE). For the convergent validity, the AVE value must be higher than 0.5, which indicates that at least $50 \%$ variance of the indicators can be explained by the latent variable (Fornell \& Larcker, 1981). For the discriminant validity, there is a need for a suitable Average Variance Extracted (AVE) analysis. In an AVE investigation, we examine to see if the SQRT (square root) of every AVE value belonging to each latent construct is much greater than any correlation among any pair of latent variables. As a rule of thumb, the SQRT of the AVE of each variable should be much greater than the correlation of the particular variable with any of the other variables in the model and should be at least 0.50 (Fornell \& Larcker, 1981; Hair et al., 2012). 
Table 3: Convergent Validity

\begin{tabular}{|l|l|l|l|}
\hline Variables & No. of items & AVE (\%) & AVE \\
\hline ECOI & 8 & 52.140 & 0.5214 \\
\hline SOCI & 6 & 52.094 & 0.5209 \\
\hline CULI & 7 & 51.700 & 0.5170 \\
\hline ENVI & 5 & 65.041 & 0.6504 \\
\hline QOL & 22 & 49.510 & 0.4951 \\
\hline SFT & 6 & 44.323 & 0.4432 \\
\hline
\end{tabular}

The above-mentioned table shows the convergent validity of all the constructs used in this pilot study. The values for Economic Impact (ECOI), Social Impact (SCOI), Cultural Impact (CULI), and Environmental Impact (ENVI), have the values above the threshold level of 0.05 , showing that constructs are valid. However, the values of QOL and SFT are slightly lower than the threshold value, which is also considered to be acceptable. The lower values can be due to the smaller sample size which could be improved with the increase in data.

Table 4: Discriminant Validity (Fornell-Larcker)

\begin{tabular}{|l|l|l|l|l|l|l|}
\hline Variable & ECOI & SCOI & CULI & ENVI & QOL & SFT \\
\hline ECOI & $\mathbf{0 . 7 2 2 0}$ & & & & & \\
\hline SCOI & 0.5565 & $\mathbf{0 . 7 2 1 7}$ & & & & \\
\hline CULI & 0.4596 & 0.5026 & $\mathbf{0 . 7 1 9 0}$ & & & \\
\hline ENVI & 0.2052 & 0.3624 & 0.2171 & $\mathbf{0 . 8 0 6 4}$ & & \\
\hline QOL & 0.0003 & 0.0013 & 0.0010 & 0.0057 & $\mathbf{0 . 7 0 3 6}$ & \\
\hline SFT & 0.0001 & 0.0005 & 0.0388 & 0.0077 & 0.0067 & $\mathbf{0 . 6 6 5 7}$ \\
& & & & & & \\
\hline
\end{tabular}

Note: Square root of AVE on the diagonal

The above table indicates the results of the AVE analysis. It can be certainly seen that the values of AVE is above 0.5 and are exceeding the values of correlation for each variable in the table.

\subsubsection{Inter-Item correlations}

The tables given below show the inter-item correlations of all the variables used in this study. The table shows how each item of the study correlates to all other items. The 
perfect range of average inter-item correlation is between 0.15 to 0.50 ; if less than this, then the items are not effectively correlated and also not assessing a similar construct, or an idea very well (if at all). If it's more than 0.50 then the items are so close as to be almost repeated. All the items show correlations with one another; however, there are some lower values as well representing that these items have less correlation with each other but are considered acceptable.

Table 5(a): Inter-Item Correlation Matrix (Economic Impact)

\begin{tabular}{|c|c|c|c|c|c|c|c|c|}
\hline & $\begin{array}{r}\text { ECO } \\
-1 \\
\end{array}$ & $\begin{array}{r}\text { ECO } \\
22 \\
\end{array}$ & $\begin{array}{r}\text { ECO } \\
\quad 3 \\
\end{array}$ & $\begin{array}{r}\text { ECO } \\
-4 \\
\end{array}$ & $\begin{array}{r}\text { ECO } \\
\quad 5 \\
\end{array}$ & $\begin{array}{r}\text { ECO } \\
\quad 6 \\
\end{array}$ & $\begin{array}{r}\text { ECO } \\
-7 \\
\end{array}$ & $\begin{array}{r}\text { ECO } \\
\quad 8 \\
\end{array}$ \\
\hline $\begin{array}{c}\mathrm{ECO} \\
-1 \\
\end{array}$ & 1.000 & .524 & .633 & .456 & .463 & .408 & .675 & .399 \\
\hline $\begin{array}{c}\mathrm{ECO} \\
\_2 \\
\end{array}$ & .524 & 1.000 & .859 & .353 & .498 & .422 & .534 & .414 \\
\hline $\begin{array}{c}\text { ECO } \\
-3 \\
\end{array}$ & .633 & .859 & 1.000 & .390 & .507 & .433 & .585 & .364 \\
\hline $\begin{array}{c}\mathrm{ECO} \\
-4 \\
\end{array}$ & .456 & .353 & .390 & 1.000 & .407 & .154 & .271 & .362 \\
\hline $\begin{array}{c}\text { ECO } \\
5 \\
\end{array}$ & .463 & .498 & .507 & .407 & 1.000 & .360 & .479 & .314 \\
\hline $\begin{array}{l}\text { ECO } \\
\_6\end{array}$ & .408 & .422 & .433 & .154 & .360 & 1.000 & .582 & .186 \\
\hline $\begin{array}{l}\text { ECO } \\
-7\end{array}$ & .675 & .534 & .585 & .271 & .479 & .582 & 1.000 & .298 \\
\hline $\begin{array}{l}\text { ECO } \\
\_8\end{array}$ & .399 & .414 & .364 & .362 & .314 & .186 & .298 & 1.000 \\
\hline
\end{tabular}

Table 5(b): Inter-Item Correlation Matrix (Social Impact)

\begin{tabular}{|l|r|r|r|r|r|r|}
\hline & SOC_1 & SOC_2 & SOC_3 & SOC_4 & SOC_5 & SOC_6 \\
\hline SOC_1 & 1.000 & .494 & .588 & .297 & .123 & .256 \\
\hline SOC_2 & .494 & 1.000 & .772 & .613 & .404 & .352 \\
\hline SOC_3 & .588 & .772 & 1.000 & .367 & .460 & .472 \\
\hline SOC_4 & .297 & .613 & .367 & 1.000 & .235 & .112 \\
\hline SOC_5 & .123 & .404 & .460 & .235 & 1.000 & .626 \\
\hline SOC_6 & .256 & .352 & .472 & .112 & .626 & 1.000 \\
\hline \hline
\end{tabular}

Sukkur IBA Journal of Management and Business - SIJMB | Vol 7 No. 2 July - December 2020 @ Sukkur IBA University 
Table 5(c): Inter-Item Correlation Matrix (Cultural Impact)

\begin{tabular}{|c|c|c|c|c|c|c|c|}
\hline & $\begin{array}{r}\mathrm{CUL}_{-} \\
\end{array}$ & $\begin{array}{r}\mathrm{CUL}_{-} \\
\end{array}$ & $\begin{array}{r}\mathrm{CUL}_{-} \\
\end{array}$ & $\begin{array}{r}\mathrm{CUL}_{-} \\
4\end{array}$ & $\begin{array}{r}\mathrm{CUL}_{-} \\
5\end{array}$ & $\begin{array}{r}\mathrm{CUL}_{-} \\
6\end{array}$ & $\begin{array}{r}\mathrm{CUL}_{-} \\
\end{array}$ \\
\hline $\begin{array}{l}\mathrm{CUL}_{-} \\
1\end{array}$ & 1.000 & .700 & .359 & .396 & .440 & .410 & .264 \\
\hline $\begin{array}{l}\mathrm{CUL}_{-} \\
2 \\
\end{array}$ & .700 & 1.000 & .516 & .382 & .479 & .414 & .345 \\
\hline $\begin{array}{l}\mathrm{CUL}_{-} \\
3\end{array}$ & .359 & .516 & 1.000 & .537 & .341 & .357 & .296 \\
\hline $\begin{array}{l}\mathrm{CUL}_{-} \\
4 \\
\end{array}$ & .396 & .382 & .537 & 1.000 & .316 & .264 & .168 \\
\hline $\begin{array}{l}\mathrm{CUL}_{-} \\
5\end{array}$ & .440 & .479 & .341 & .316 & 1.000 & .781 & .607 \\
\hline $\begin{array}{l}\mathrm{CUL}_{-} \\
6\end{array}$ & .410 & .414 & .357 & .264 & .781 & 1.000 & .677 \\
\hline $\begin{array}{l}\mathrm{CUL}_{-} \\
7\end{array}$ & .264 & .345 & .296 & .168 & .607 & .677 & 1.000 \\
\hline
\end{tabular}

Table 5(d): Inter-Item Correlation Matrix (Environmental Impact)

\begin{tabular}{|l|r|r|r|r|r|}
\hline & ENV_1 & ENV_2 & ENV_3 & ENV_4 & ENV_5 \\
\hline ENV_1 & 1.000 & .543 & .657 & .632 & .307 \\
\hline ENV_2 & .543 & 1.000 & .637 & .537 & .459 \\
\hline ENV_3 & .657 & .637 & 1.000 & .747 & .409 \\
\hline ENV_4 & .632 & .537 & .747 & 1.000 & .366 \\
\hline ENV_5 & .307 & .459 & .409 & .366 & 1.000 \\
\hline
\end{tabular}

Table 5(e): Inter-Item Correlation Matrix (Quality of life)

\begin{tabular}{|l|r|r|r|}
\hline & QOL_1 & QOL_2 & QOL_3 \\
\hline QOL_1 & 1.000 & .847 & .326 \\
\hline QOL_2 & .847 & 1.000 & .358 \\
\hline QOL_3 & .326 & .358 & 1.000 \\
\hline
\end{tabular}

Sukkur IBA Journal of Management and Business - SIJMB | Vol 7 No. 2 July - December 2020 ○ Sukkur IBA University 
Table 5(f): Inter-Item Correlation Matrix (Material wellbeing domain)

\begin{tabular}{|l|r|r|r|r|r|}
\hline & MWBD_ & MWBD_ & MWBD_ & MWBD_ & MWBD_ \\
\hline $\begin{array}{l}\text { MWBD_ } \\
1\end{array}$ & 1.000 & .763 & .557 & .234 & .239 \\
\hline $\begin{array}{l}\text { MWBD_ } \\
2\end{array}$ & .763 & 1.000 & .465 & .301 & .229 \\
\hline $\begin{array}{l}\text { MWBD_ } \\
3\end{array}$ & .557 & .465 & 1.000 & .447 & .168 \\
\hline $\begin{array}{l}\text { MWBD_ } \\
4\end{array}$ & .234 & .301 & .447 & 1.000 & .497 \\
\hline $\begin{array}{l}\text { MWBD_ } \\
5\end{array}$ & .239 & .229 & .168 & .497 & 1.000 \\
\hline
\end{tabular}

Table 5(g): Inter-Item Correlation Matrix (Community wellbeing domain)

\begin{tabular}{|l|r|r|r|r|}
\hline & CWBD_1 & CWBD_2 & CWBD_3 & CWBD_4 \\
\hline CWBD_1 & 1.000 & .592 & .448 & .326 \\
\hline CWBD_2 & .592 & 1.000 & .589 & .444 \\
\hline CWBD_3 & .448 & .589 & 1.000 & .168 \\
\hline CWBD_4 & .326 & .444 & .168 & 1.000 \\
\hline
\end{tabular}

Table 5(h): Inter-Item Correlation Matrix (Emotional wellbeing domain)

\begin{tabular}{|c|r|r|r|r|r|}
\hline & EWBD_1 & EWBD_2 & EWBD_3 & EWBD_4 & EWBD_5 \\
\hline EWBD_1 & 1.000 & .656 & .184 & .284 & .118 \\
\hline EWBD_2 & .656 & 1.000 & .292 & .270 & .293 \\
\hline EWBD_3 & .184 & .292 & 1.000 & .694 & .570 \\
\hline EWBD_4 & .284 & .270 & .694 & 1.000 & .738 \\
\hline EWBD_5 & .118 & .293 & .570 & .738 & 1.000 \\
\hline
\end{tabular}


Table 5(i): Inter-Item Correlation Matrix (Health \& Safety wellbeing domain)

\begin{tabular}{|l|c|c|c|c|c|}
\hline & $\begin{array}{c}\text { HSWBD_ } \\
\mathbf{1}\end{array}$ & $\begin{array}{c}\text { HSWBD_ } \\
\mathbf{2}\end{array}$ & $\begin{array}{c}\text { HSWBD_ } \\
\mathbf{3}\end{array}$ & $\begin{array}{c}\text { HWB } \\
\mathbf{4}\end{array}$ & $\begin{array}{c}\text { HSWBD_ } \\
\mathbf{5}\end{array}$ \\
\hline $\begin{array}{l}\text { HSWBD_ } \\
1\end{array}$ & 1.000 & .218 & .264 & .328 & .472 \\
\hline $\begin{array}{l}\text { HSWBD_ } \\
2\end{array}$ & .218 & 1.000 & .051 & .525 & .132 \\
\hline $\begin{array}{l}\text { HSWBD_ } \\
3\end{array}$ & .264 & .051 & 1.000 & .010 & .277 \\
\hline $\begin{array}{l}\text { HSWBD_ } \\
4\end{array}$ &. .328 & .525 & .010 & 1.000 & .378 \\
\hline $\begin{array}{l}\text { HSWBD_ } \\
5\end{array}$ & .472 & .132 & .277 & .378 & 1.000 \\
\hline
\end{tabular}

Table 5(j): Inter-Item Correlation Matrix (Support for tourism)

\begin{tabular}{|l|r|r|r|r|r|r|}
\hline & ST1 & ST2 & ST3 & ST4 & ST5 & ST6 \\
\hline SFT1 & 1.000 & .613 & .342 & .225 & .187 & .190 \\
\hline SFT2 & .613 & 1.000 & .467 & .190 & .138 & .276 \\
\hline SFT3 & .342 & .467 & 1.000 & .444 & .386 & .175 \\
\hline SFT4 & .225 & .190 & .444 & 1.000 & .657 & .151 \\
\hline SFT5 & .187 & .138 & .386 & .657 & 1.000 & .482 \\
\hline SFT6 & .190 & .276 & .175 & .151 & .482 & 1.000 \\
\hline
\end{tabular}

\section{Conclusion \& Policy Implications}

\subsection{Discussions}

Residents' support for tourism in a community is an essential component of the tourism industry for the success of tourism development in any tourist destination. Therefore, it is essential to understand how residents' positive attitudes and perceptions can be fostered for their further support for tourism development in their respective communities. To achieve successful tourism development in the host community, support from their residents is important. Because tourism depends profoundly upon the willingness of the residents, and their support is important for its future growth, as well as for its success and sustainability in the long term. Therefore, the understanding of residents' perceptions and encouragement of such support is of great prominence for the local management, policymakers, and business organizations (Lee, 2013). As 
discussed earlier, the pretest is essential to conduct before the main study as it provides the researcher with an opportunity to measure, improve, and adapt the scales used. Further, this pretest is used for attaining the immediate empirical evidence and knowledge to further improve the research design and conceptualization of the study, its interpretation of findings, and finally outcomes of the study. The survey instrument of this pilot study is adopted after an in-depth study of the literature review.

\subsection{Implications}

The investigation of this study indicates that the values of reliability statistics (Cronbach's Alpha) are at an acceptable level as they met the threshold value. Therefore, the survey instrument of this study is manageable for further data gathering. Furthermore, the subject and field experts inspected and validated the content and face of the survey instrument. The constructs selected for this study have substantial value in tourism literature. Besides, this present study provides the social lab contribution in the existing literature, as in the Pakistani context limited literature is available on tourism studies. However, tourism studies concerning residents' perceptions of tourism impacts, their QOL, and their support for tourism development have not been reported yet in any dimension. Therefore, the findings will considerably contribute to the body of knowledge of this specific area.

\subsection{Limitations and Future Research Agendas}

Like any other study, this study has also certain limitations that open possibilities for future research on tourism and their related indicators. In the present study, four major life domains were selected to measure the residents' QOL. However, there might be more wellbeing domains such as work-life, social life, travel life, and, household life. Therefore, future research could replicate the study findings with a more comprehensive category of wellbeing domains for measuring residents' QOL. The current study has collected data from the residents of Hunza Valley. If the study gathered data from diverse regions and tourist destinations, then the strength of the correlation between the six variables may show some variations. As a result, future research may consider gathering data from diverse destinations that may show a different level of tourism growth. This nature of investigation can help in identifying by validating empirically that how residents' QOL may be dissimilar based on the level of tourism growth. In light of the above limitations, future research is encouraged to be undertaken to determine this model more extensively. Thus, this research study providing a benchmark to conduct further studies in this particular area because particularly we do not have generalized results so far. It is, therefore, recommended that certain other elements affect the residents' SFT other than the variables included in this study, which may be included in further researches to increase the authenticity of the study.

Sukkur IBA Journal of Management and Business - SIJMB | Vol 7 No. 2 July - December 2020 ๑ Sukkur IBA University 


\section{References}

Almeida-García, F., Peláez-Fernández, M. Á., Balbuena-Vázquez, A., \& CortésMacias, R. (2016). Residents' perceptions of tourism development in Benalmádena (Spain). Tourism Management, 54, 259-274. https://doi.org/10.1016/j.tourman.2015.11.007

Andereck, K. L., Valentine, K. M., Vogt, C. A., \& Knopf, R. C. (2007). A Cross-cultural Analysis of Tourism and Quality of Life Perceptions. Journal of Sustainable Tourism, 15(5), 483-502. https://doi.org/10.2167/jost612.0

Andereck, K. L., \& Vogt, C. A. (2000). The Relationship between Residents' Attitudes toward Tourism and Tourism Development Options. Journal of Travel Research, 39(1), 27-36. https://doi.org/10.1177/004728750003900104

Ap, J. (1992). Residents' perceptions on tourism impacts. Annals of Tourism Research, 19(4), 665-690. https://doi.org/10.1016/0160-7383(92)90060-3

Brida, J. G., Disegna, M., \& Osti, L. (2014). Publications. Tourismos : An International Multidisciplinary Journal of Tourism, 9, 37-71.

Brida, Juan Gabriel, Disegna, M., \& Osti, L. (2014). RESIDENTS' PERCEPTIONS OF TOURISM IMPACTS AND ATTITUDES TOWARDS TOURISM POLICIES. 9(1), 35.

Burns, R. P., \& Burns, R. (2008). Business research methods and statistics using SPSS. Sage.

Butler, R. W. (1980). The Concept of a Tourist Area Cycle of Evolution: Implications for Management of Resources. The Canadian Geographer / Le Géographe Canadien, 24(1), 5-12. https://doi.org/10.1111/j.1541-0064.1980.tb00970.x

Choi, H. C., \& Murray, I. (2010). Resident attitudes toward sustainable community tourism. Journal of Sustainable Tourism, 18(4), 575-594. https://doi.org/10.1080/09669580903524852

Choi, H.-S. C., \& Sirakaya, E. (2005). Measuring Residents' Attitude toward Sustainable Tourism: Development of Sustainable Tourism Attitude Scale. Journal of Travel Research, 43(4), 380-394. https://doi.org/10.1177/0047287505274651

Croes, R. (2012). Assessing Tourism Development from Sen's Capability Approach. Journal of Travel Research, 51(5), 542-554. https://doi.org/10.1177/0047287511431323

Cronbach, L. J. (1951). Coefficient alpha and the internal structure of tests. Psychometrika, 16(3), 297-334. https://doi.org/10.1007/BF02310555

DongWan, K., \& Stewart, W. P. (2002). A structural equation model of residents' attitudes for tourism development. Tourism Management, 23(5), 521-530.

Dyer, P., Gursoy, D., Sharma, B., \& Carter, J. (2007). Structural modeling of resident perceptions of tourism and associated development on the Sunshine Coast, Australia. Tourism $\quad$ Management, 28(2), 409-422. https://doi.org/10.1016/j.tourman.2006.04.002 
Fallon, P., \& Schofield, P. (2006). The dynamics of destination attribute importance. Journal of Business Research, 59(6), 709-713. https://doi.org/10.1016/j.jbusres.2006.01.007

Field, A. (2013). Discovering Statistics Using IBM SPSS Statistics. SAGE.

Fornell, C., \& Larcker, D. F. (1981). Evaluating Structural Equation Models with Unobservable Variables and Measurement Error. Journal of Marketing Research, 18(1), 39-50. JSTOR. https://doi.org/10.2307/3151312

Gursoy, D., Jurowski, C., \& Uysal, M. (2002). Resident attitudes: A Structural Modeling Approach. Annals of Tourism Research, 29(1), 79-105. https://doi.org/10.1016/S0160-7383(01)00028-7

Gursoy, D., Ouyang, Z., Nunkoo, R., \& Wei, W. (2018). Residents' impact perceptions of and attitudes towards tourism development: A meta-analysis. Journal of Hospitality Marketing \& Management, 0(0), 1-28. https://doi.org/10.1080/19368623.2018.1516589

Hair, J. F., Sarstedt, M., Pieper, T. M., \& Ringle, C. M. (2012). The Use of Partial Least Squares Structural Equation Modeling in Strategic Management Research: A Review of Past Practices and Recommendations for Future Applications. Long Range Planning, 45(5-6), 320-340. https://doi.org/10.1016/j.lrp.2012.09.008

Iroegbu, H., \& Chen, J. S. (2001). Urban Residents' Reaction Toward Tourism Development: Do Subgroups Exist? [Text]. https://doi.org/info:doi/10.3727/108354201108749809

Jurowski, C., \& Gursoy, D. (2004). DISTANCE EFFECTS ON RESIDENTS' ATTITUDES TOWARD TOURISM. Annals of Tourism Research, 31(2), 296-312. https://doi.org/10.1016/j.annals.2003.12.005

Jurowski, C., Uysal, M., \& Williams, D. R. (1997). A Theoretical Analysis of Host Community Resident Reactions to Tourism. Journal of Travel Research, 36(2), 3-11. https://doi.org/10.1177/004728759703600202

Kim, K. (2002). The effects of tourism impacts upon Quality of Life of residents in the community [PhD Thesis, Virginia Polytechnic Institute and State University]. https://vtechworks.lib.vt.edu/bitstream/handle/10919/29954/Title_and_Text.p df? sequence $=1$

Kim, K., Uysal, M., \& Sirgy, M. J. (2013a). How does tourism in a community impact the quality of life of community residents? Tourism Management, 36, 527-540. https://doi.org/10.1016/j.tourman.2012.09.005

Kim, K., Uysal, M., \& Sirgy, M. J. (2013b). How does tourism in a community impact the quality of life of community residents? Tourism Management, 36, 527-540. https://doi.org/10.1016/j.tourman.2012.09.005

Ko, D.-W., \& Stewart, W. P. (2002). A structural equation model of residents' attitudes for tourism development. Tourism Management, 23(5), 521-530. https://doi.org/10.1016/S0261-5177(02)00006-7

Lee, T. H. (2013). Influence analysis of community resident support for sustainable tourism development. Tourism Management, 34, 37-46. https://doi.org/10.1016/j.tourman.2012.03.007 
Lin, Z., Chen, Y., \& Filieri, R. (2017). Resident-tourist value co-creation: The role of residents' perceived tourism impacts and life satisfaction. Tourism Management, 61, 436-442. https://doi.org/10.1016/j.tourman.2017.02.013

Liu, J. C., Sheldon, P. J., \& Var, T. (1987). Resident perception of the environmental impacts of tourism. Annals of Tourism Research, 14(1), 17-37.

Nunkoo, R., \& Ramkissoon, H. (2010). Small island urban tourism: A residents' perspective. Current Issues in Tourism, 13(1), 37-60. https://doi.org/10.1080/13683500802499414

Nunkoo, R., \& Ramkissoon, H. (2011). Residents' Satisfaction With Community Attributes and Support for Tourism. Journal of Hospitality \& Tourism Research, 35(2), 171-190. https://doi.org/10.1177/1096348010384600

Nunkoo, R., \& So, K. K. F. (2016). Residents' Support for Tourism: Testing Alternative Structural Models. Journal of Travel Research, 55(7), 847-861. https://doi.org/10.1177/0047287515592972

Perdue, R. R., Long, P. T., \& Allen, L. (1990). Resident support for tourism development. Annals of Tourism Research, 17(4), 586-599. https://doi.org/10.1016/0160-7383(90)90029-Q

Perdue, R. R., Long, P. T., \& Kang, Y. S. (1999). Boomtown Tourism and Resident Quality of Life: The Marketing of Gaming to Host Community Residents. Journal of Business Research, 44(3), 165-177. https://doi.org/10.1016/S01482963(97)00198-7

Peters, M., \& Schuckert, M. (2014). Tourism Entrepreneurs' Perception of Quality of Life: An Explorative Study. Tourism Analysis, 19(6), 731-740. https://doi.org/10.3727/108354214X14146846679484

Pizam, A. (1978). Tourism's Impacts: The Social Costs to the Destination Community as Perceived by Its Residents. Journal of Travel Research, 16(4), 8-12. https://doi.org/10.1177/004728757801600402

Robson, J., \& Robson, I. (1996). From shareholders to stakeholders: Critical issues for tourism marketers. Tourism Management, 17(7), 533-540. https://doi.org/10.1016/S0261-5177(96)00070-2

Rosenthal, R., \& Rosnow, R. L. (1984). Essentials of behavioral research: Methods and data analysis (2nd ed.). McGraw-Hill Higher Education.

Sekaran, U., \& Bougie, R. (2016). Research Methods For Business: A Skill Building Approach. John Wiley \& Sons.

Sinclair-Maragh, G., \& Gursoy, D. (2016). A Conceptual Model of Residents' Support for Tourism Development in Developing Countries. Tourism Planning \& Development, 13(1), 1-22. https://doi.org/10.1080/21568316.2015.1047531

Snaith, T., \& Haley, A. (1999). Residents' opinions of tourism development in the historic city of York, England. Tourism Management, 20(5), 595-603. https://doi.org/10.1016/S0261-5177(99)00030-8

Stylidis, D., Biran, A., Sit, J., \& Szivas, E. M. (2014a). Residents' support for tourism development: The role of residents' place image and perceived tourism impacts. Tourism Management, 45, 260-274. https://doi.org/10.1016/j.tourman.2014.05.006 
Stylidis, D., Biran, A., Sit, J., \& Szivas, E. M. (2014b). Residents' support for tourism development: The role of residents' place image and perceived tourism impacts. Tourism Management, 45, 260-274. https://doi.org/10.1016/j.tourman.2014.05.006

Woo, E., Kim, H., \& Uysal, M. (2015a). Life satisfaction and support for tourism development. Annals of Tourism Research, 50, 84-97. https://doi.org/10.1016/j.annals.2014.11.001

Woo, E., Kim, H., \& Uysal, M. (2015b). Life satisfaction and support for tourism development. Annals of Tourism Research, 50, 84-97. https://doi.org/10.1016/j.annals.2014.11.001

Woo, E., Uysal, M., \& Sirgy, M. J. (2016). Tourism Impact and Stakeholders' Quality of Life. Journal of Hospitality \& Tourism Research, 42(2), 260-286. https://doi.org/10.1177/1096348016654971

Yoon, Y., Gursoy, D., \& Chen, J. S. (2001). Validating a tourism development theory with structural equation modeling. Tourism Management, 22(4), 363-372. https://doi.org/10.1016/S0261-5177(00)00062-5 